\title{
The 2004 Indian Ocean tsunami: Tsunami source model from satellite altimetry
}

\author{
Kenji Hirata ${ }^{1}$, Kenji Satake ${ }^{2}$, Yuichiro Tanioka ${ }^{3}$, Tsurane Kuragano ${ }^{4}$, Yohei Hasegawa ${ }^{5}$, Yutaka Hayashi ${ }^{5}$, and Nobuo Hamada ${ }^{6}$ \\ ${ }^{1}$ Program for Deep Sea Research, IFREE, Japan Agency for Marine-Earth Science and Technology, Natsushima 2-15, Yokosuka 237-0061, Japan \\ ${ }^{2}$ Active Fault Research Center, National Institute of Advanced Industrial Science and Technology, Site C7 1-1-1 Higashi, Tsukuba 305-8567, Japan \\ ${ }^{3}$ Institute of Seismology and Volcanology, Hokkaido University, N10W8 Kita-ku, Sapporo 060-0810, Japan \\ ${ }^{4}$ Global Environment and Marine Department, Japan Meteorological Agency, Otemachi 1-3-4, Chiyoda-ku, Tokyo 100-8122, Japan \\ ${ }^{5}$ Seismilogy and Volcanology Research Department, Meteorological Research Institute, 1-1 Nagamine, Tsukuba 305-005, Japan \\ ${ }^{6}$ Sapporo District Meteorological Observatory, N2W18-2, Chuo-ku, Sapporo 060-0002, Japan
}

(Received July 8, 2005; Revised October 14, 2005; Accepted October 21, 2005; Online published February 17, 2006)

\begin{abstract}
Satellite altimetry measurements of sea surface heights for the first-time captured the Indian Ocean tsunami generated from the December 2004 great Sumatra earthquake. Analysis of the sea surface height profile suggests that the tsunami source, or the seafloor deformation, of the great earthquake propagated to the north at an extremely slow speed of less than $1 \mathrm{~km} / \mathrm{sec}$ on average for the entire 1300-km-long segment along the northern Sumatra-Nicobar-Andaman Trench. The extremely slow propagation speed produces a very long duration of tens minutes, longer than earthquake source duration estimated $(480-500 \mathrm{sec})$ from short-period $P$-wave radiation. The satellite altimetry data requires a total seismic moment of $9.86 \times 10^{22} \mathrm{Nm}(\mathrm{Mw}=9.3)$. This estimate is approximately 2.5 times larger than the value from long-period surface wave analysis but nearly the same as that from the ultra-long-period normal mode study. The maximum amount of slip $(\sim 30 \mathrm{~m})$ is identified in an offshore region closest to the northern most part of Sumatra where the largest tsunami run-up heights were observed.
\end{abstract}

Key words: 2004 Sumatra earthquake, tsunami, source model, satellite, Indian Ocean.

\section{Introduction}

A great earthquake occurred northwest of Sumatra at 0:59 UTC, December 26, 2004. USGS/NEIC (United States Geological Survey/National Earthquake Information Center) and Harvard University assigned a momentmagnitude (Mw) of 9.0 to this earthquake. Soon afterwards an analysis of the longest period normal mode yielded a seismic moment of $1.0 \times 10^{23} \mathrm{Nm}$ and revised the momentmagnitude as Mw 9.3 (Stein and Okal, 2005).

The earthquake generated a devastating tsunami throughout the Indian Ocean. Assuming that the one-day aftershock distribution is representative of the earthquake rupture zone, the total length is approximately $1400 \mathrm{~km}$ along the northern Sumatra-Nicobar-Andaman trench (Fig. 1). The tsunami travel times at tide gauge stations around the Indian Ocean, however, suggested that the tsunami source area was confined with the southern 600 to $800 \mathrm{~km}$ zone (Lay et al., 2005).

The maximum tsunami height of 13-49 $\mathrm{m}$ was observed on the west coast of Banda Aceh, Sumatra (International Tsunami Survey Team, 2005; Tsunami Field Survey Team in Banda Aceh of Indonesia, 2005) whereas tsunami heights were 1-7 $\mathrm{m}$ at the Nicobar and Andaman Islands (Department of Ocean Development, 2005). The observed distribution of tsunami heights may be related to a possible hetero-

Copyright (c) The Society of Geomagnetism and Earth, Planetary and Space Sciences (SGEPSS); The Seismological Society of Japan; The Volcanological Society of Japan; The Geodetic Society of Japan; The Japanese Society for Planetary Sciences; TERRAPUB geneity of the tsunami excitation strength along the trench.

Two hours after the occurrence of the great earthquake, two NASA/French Space Agency's joint mission satellites "Jason-1" and "TOPEX/Poseidon" passed across the Indian Ocean and measured sea surface height ( $\mathrm{SSH}$ ) disturbed by the Indian Ocean tsunami from the great Sumatra earthquake (Fig. 1(a)) (Gower, 2005). Previous modeling explained the observed satellite SSH data successfully (Titov, 2005) except for a region between $0^{\circ} \mathrm{N}$ and $15^{\circ} \mathrm{N}$ in the Jason-1 observations. Lay et al. (2005) suggested that a slow slip is required for the SSH observation between $5^{\circ} \mathrm{N}$ and $14^{\circ} \mathrm{N}$. In this study, we analyze the SSH data from the two satellites to investigate heterogeneous source model of the Indian Ocean tsunami.

\section{Sea Surface Heights observed from Satellites}

Satellites "Jason-1" and "TOPEX/Poseidon" passed across the Indian Ocean from southwest to northeast at a speed of approximately $7 \mathrm{~km} / \mathrm{sec}$ (Fig. 1(a)). The accuracy of satellite altimetry is less than $5 \mathrm{~cm}$ and its spatial resolution is approximately 15 minutes of the arc $(\sim 27 \mathrm{~km})$ (JPL/NASA, 2005).

Original SSH data are processed routinely to remove contributions of geoid, ocean tide, atmospheric pressure, and vapor in atmosphere. The remaining SSH data include oceanographic effects. The spatial distribution of the Indian Ocean tsunami two hours after the earthquake can be defined by SSH differences between successive cycles of satellite altimetry. For Jason-1, it is calculated from cycles 109 (passed the Equator at 02:55:24 UTC, 26 Decem- 

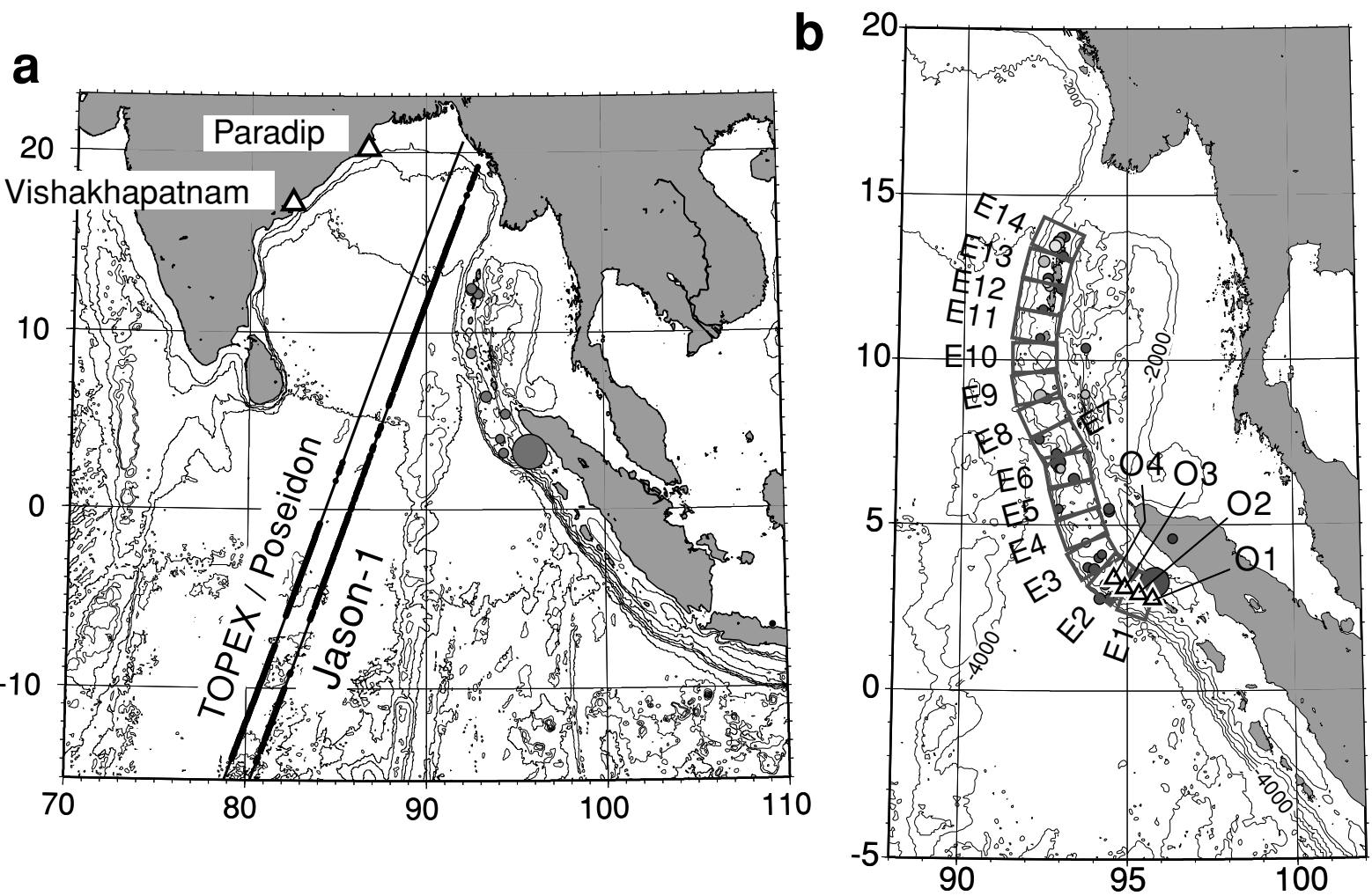

Fig. 1. (a) Ground tracks of satellite altimetry with Jason-1 and TOPEX/Poseidon (thin lines). Two satellites passed across the Indian Ocean two hours after the occurrence of the great Sumatra earthquake (Gower, 2005; JPL/NASA, 2005). Closed circles on the ground tracks indicate the points that sea surface height (SSH) difference from two successive cycles before and after the great Sumatra earthquake can be defined. The epicenters of mainshock and aftershocks two hours after the great event are also shown. (b) Subfault setting for the inversion in this study. We model the entire aftershock zone, with a length of $1400 \mathrm{~km}$ along the northern Sumatra-Nicobar-Andaman trench, using 14 subfaults placed parallel to the trench (E1-E14). $\mathrm{O}_{1}$ to $\mathrm{O}_{4}$ (triangles) indicate possible rupture initiation points. Aftershock distribution, including the mainshock epicenter, within 1 day after the occurrence of the mainshock is also shown.

\section{a}
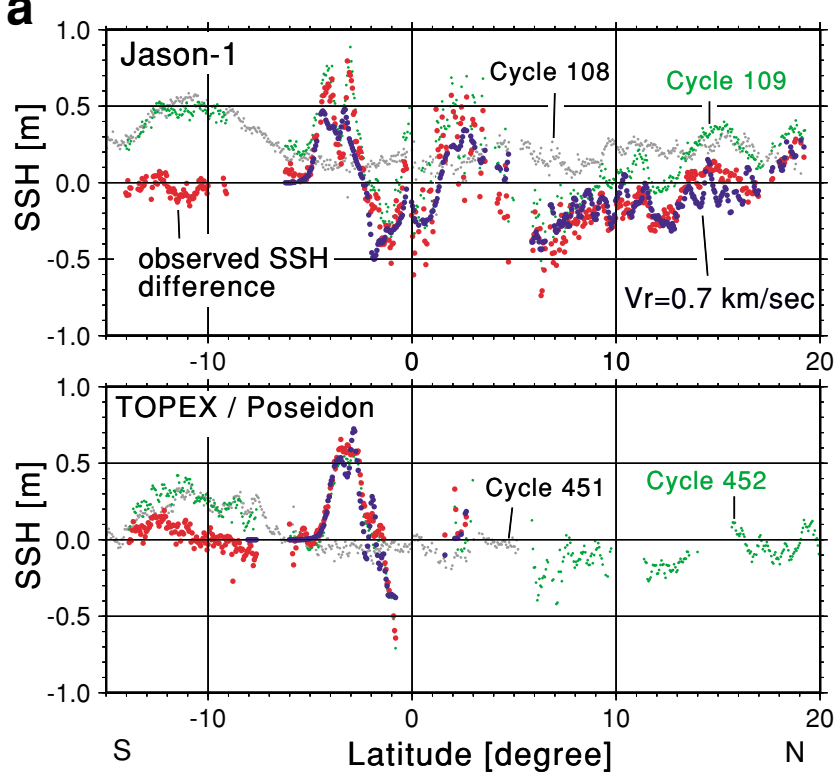

b

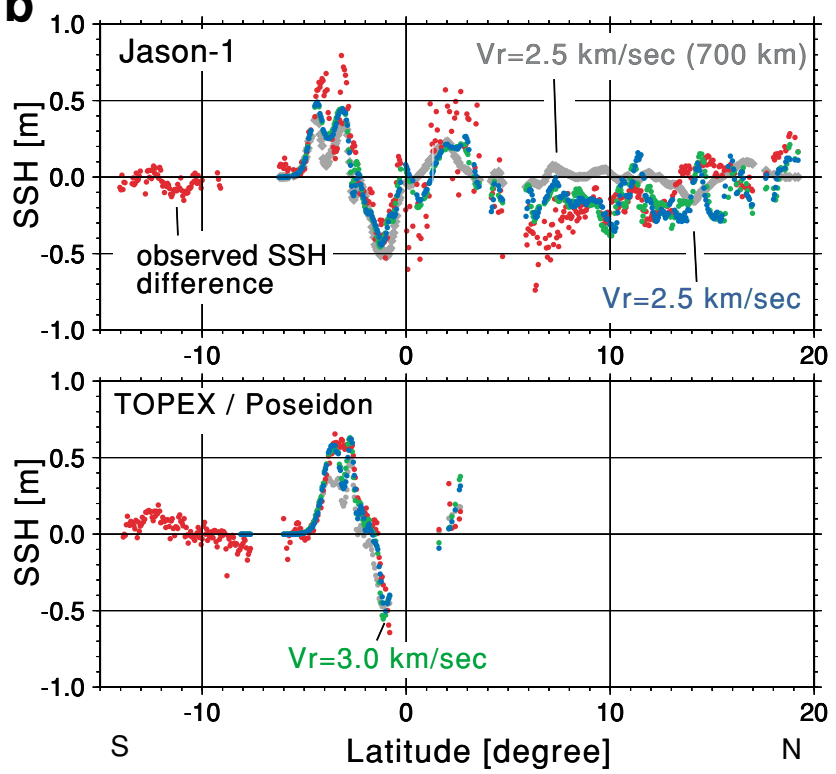

Fig. 2. (a) Observed sea surface height (SSH) by satellite altimetry from Jason-1 and TOPEX/Poseidon measurements. Gray and green dots indicate observed SSH data in cycles 108 and 109, respectively, from Jason-1 (upper panel) and those in cycles 451 and 452 , respectively, from TOPEX/Poseidon (lower panel). The Indian Ocean tsunami from the great Sumatra earthquake can be defined by taking the difference between successive cycle pairs (Red circles). Blue circles depict the best-fit synthetic SSH computed from an extremely slow propagation model with its velocity of $0.7 \mathrm{~km} / \mathrm{sec}$. (b) Comparison of synthetic SSH distribution with observed one (red circles). Green and blue circles show the synthetics from the fast propagation models with velocities of $3.0 \mathrm{~km} / \mathrm{sec}$ and $2.5 \mathrm{~km} / \mathrm{sec}$, respectively. Gray circles show the synthetics from the fast propagation models with velocity of $2.5 \mathrm{~km} / \mathrm{sec}$ but whose source area is limited in southern $700 \mathrm{~km}$-long segment. 
Table 1. Subfault Parameters and Estimated Parameters from the Inversion.

\begin{tabular}{|c|c|c|c|c|c|c|c|c|c|c|c|}
\hline Subfault \# & $\begin{array}{l}\text { Length } \\
{[\mathrm{km}]}\end{array}$ & $\begin{array}{l}\text { Width } \\
{[\mathrm{km}]}\end{array}$ & Longitude $^{1}$ & Latitude $^{1}$ & $\begin{array}{c}\text { Depth }^{1} \\
{[\mathrm{~km}]}\end{array}$ & $\begin{array}{c}\text { Strike } \\
{\left[{ }^{\circ}\right]}\end{array}$ & $\begin{array}{l}\text { Dip } \\
{\left[{ }^{\circ}\right]}\end{array}$ & $\begin{array}{c}\text { Rake } \\
{\left[{ }^{\circ}\right]}\end{array}$ & Amount of slip & $\begin{array}{l}M o^{2} \\
{[\mathrm{~m}]}\end{array}$ & $\begin{array}{c}\text { Mw_sub } \\
{[\mathrm{Nm}]}\end{array}$ \\
\hline E14 & 100 & 150 & 92.01 & 13.51 & 10 & 25 & 10 & 130 & $0.0 \pm 4.3$ & $0.00 \mathrm{E}+00$ & - \\
\hline E13 & 100 & 150 & 91.78 & 12.51 & 10 & 15 & 10 & 120 & $27.2 \pm 3.6$ & $1.43 \mathrm{E}+22$ & 8.70 \\
\hline E12 & 100 & 150 & 91.63 & 11.56 & 10 & 10 & 10 & 115 & $25.7 \pm 2.2$ & $1.35 \mathrm{E}+22$ & 8.69 \\
\hline E11 & 100 & 150 & 91.48 & 10.66 & 10 & 10 & 10 & 115 & $6.1 \pm 1.6$ & $3.20 \mathrm{E}+21$ & 8.27 \\
\hline E10 & 100 & 150 & 91.51 & 9.60 & 10 & 0 & 10 & 106 & $12.0 \pm 1.5$ & $6.30 \mathrm{E}+21$ & 8.47 \\
\hline E9 & 100 & 150 & 91.64 & 8.60 & 10 & 350 & 10 & 99 & $1.5 \pm 2.3$ & $7.93 \mathrm{E}+20$ & 7.87 \\
\hline E8 & 100 & 150 & 92.08 & 7.64 & 10 & 335 & 10 & 86 & $11.5 \pm 2.3$ & $6.04 \mathrm{E}+21$ & 8.45 \\
\hline E7 & 100 & 150 & 92.53 & 6.78 & 10 & 330 & 10 & 90 & $9.4 \pm 2.5$ & $4.96 \mathrm{E}+21$ & 8.40 \\
\hline E6 & 100 & 150 & 92.63 & 6.12 & 10 & 350 & 10 & 100 & $23.4 \pm 2.2$ & $1.23 \mathrm{E}+22$ & 8.66 \\
\hline E5 & 100 & 150 & 92.88 & 5.18 & 10 & 345 & 10 & 102 & $10.4 \pm 2.2$ & $5.46 \mathrm{E}+21$ & 8.42 \\
\hline E4 & 100 & 150 & 93.16 & 4.15 & 10 & 340 & 10 & 105 & $29.1 \pm 2.1$ & $1.53 \mathrm{E}+22$ & 8.72 \\
\hline E3 & 100 & 150 & 93.64 & 3.33 & 10 & 330 & 10 & 104 & $14.9 \pm 2.6$ & $7.82 \mathrm{E}+21$ & 8.53 \\
\hline E2 & 100 & 150 & 94.50 & 2.57 & 10 & 310 & 10 & 91 & $0.0 \pm 3.0$ & $0.00 \mathrm{E}+00$ & - \\
\hline \multirow[t]{2}{*}{ E1 } & 100 & 150 & 95.54 & 2.13 & 10 & 290 & 10 & 71 & $16.5 \pm 2.2$ & $8.66 \mathrm{E}+21$ & 8.56 \\
\hline & & & & & & & & & total $\mathrm{Mo}=$ & $9.86 \mathrm{E}+22$ & 9.26 \\
\hline
\end{tabular}

${ }^{1}$ Values at the east corner of the upper edge in each subfault.
${ }^{2}$ Rigidty is assumed to be $3.5 \times 10^{10} \mathrm{~N} / \mathrm{m}^{2}$.

ber 2004) and 108 (04:56:52 UTC, 16 December 2004) on pass 129. For TOPEX/Poseidon, it is calculated from cycles 452 (03:01:57 UTC, 26 December 2004) and 451 (05:03:25 UTC, 16 December 2004) on pass 129. The observed SSH differences from Jason-1 and TOPEX/Poseidon show considerable water surface disturbance due to the Indian Ocean tsunami along the satellite tracks (Fig. 2(a)), although both include data gaps in each cycle pairs. Total number of observed SSH differences thus defined is 344 and 155 for Jason-1 and TOPEX/Poseidon, respectively.

\section{Inversion}

We invert the satellite SSH difference data to estimate the tsunami source model, including the effects of tsunami source propagation. Propagating tsunami source is expressed by a set of vertically displaced seafloor with different onset time. We relate each vertically displaced seafloor to slip on subfaults. Figure 1(b) shows the prescribed fault model, consisting of 14 subfaults with a trench-parallellength of $100 \mathrm{~km}$. A study of coral growth and GPS measurements in the Sumatra forearc indicated that the interseismic locked zone on subduction interface does not extend farther landward than the Mentawai Island chain west of the Sumatra (Simoes et al., 2004). We therefore set the down-dip width of subfaults to be $150 \mathrm{~km}$.

Global seismic networks poorly controlled depth of aftershocks following the Sumatra earthquake. Araki et al. (2005) suggested from ocean-bottom seismographic observation that average dip angle of the aftershock distribution is $8^{\circ}$ to $12^{\circ}$ in the outer-arc high west of northern Sumatra. We therefore assume that dip angle for each of the subfaults is $10^{\circ}$. The dip angle is nearly the same as that of the Harvard Centroid Moment Tensor (CMT) solution of the mainshock, and consistent with a possible plate interface based on an accurate hypocenter catalog (Engdahl et al., 1998).

Slip angle on each subfault is estimated from the prin-

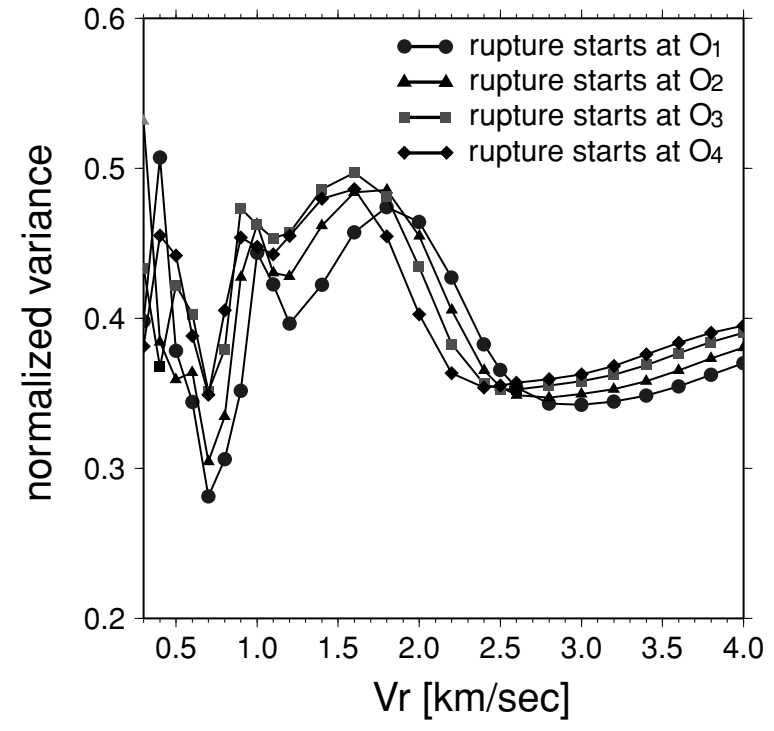

Fig. 3. Normalized variance variation with respect to rupture velocity in the inversion. We assumed four possible rupture start points, $\mathrm{O}_{1}$ to $\mathrm{O}_{4}$, as shown in Fig. 1(b). Normalized variance is defined by the root-mean-squares of difference between observed SSH difference and synthetic one, divided by the root-mean-squares of observed SSH difference.

cipal stress axis of aftershocks for the first 10 days. We selected only thrust events from the Harvard CMT catalog and assumed that the average compressional-axis directions are parallel to the slip direction on each subfault. Vertical displacement of seafloor is calculated by Okada's formula (Okada, 1985). Subfault parameters are listed in Table 1.

We compute tsunami wavefield on a spherical coordinate system from each subfault by numerically solving the shallow water (long-wave) equations using a finite difference method (Satake, 1995). The computation region is shown 


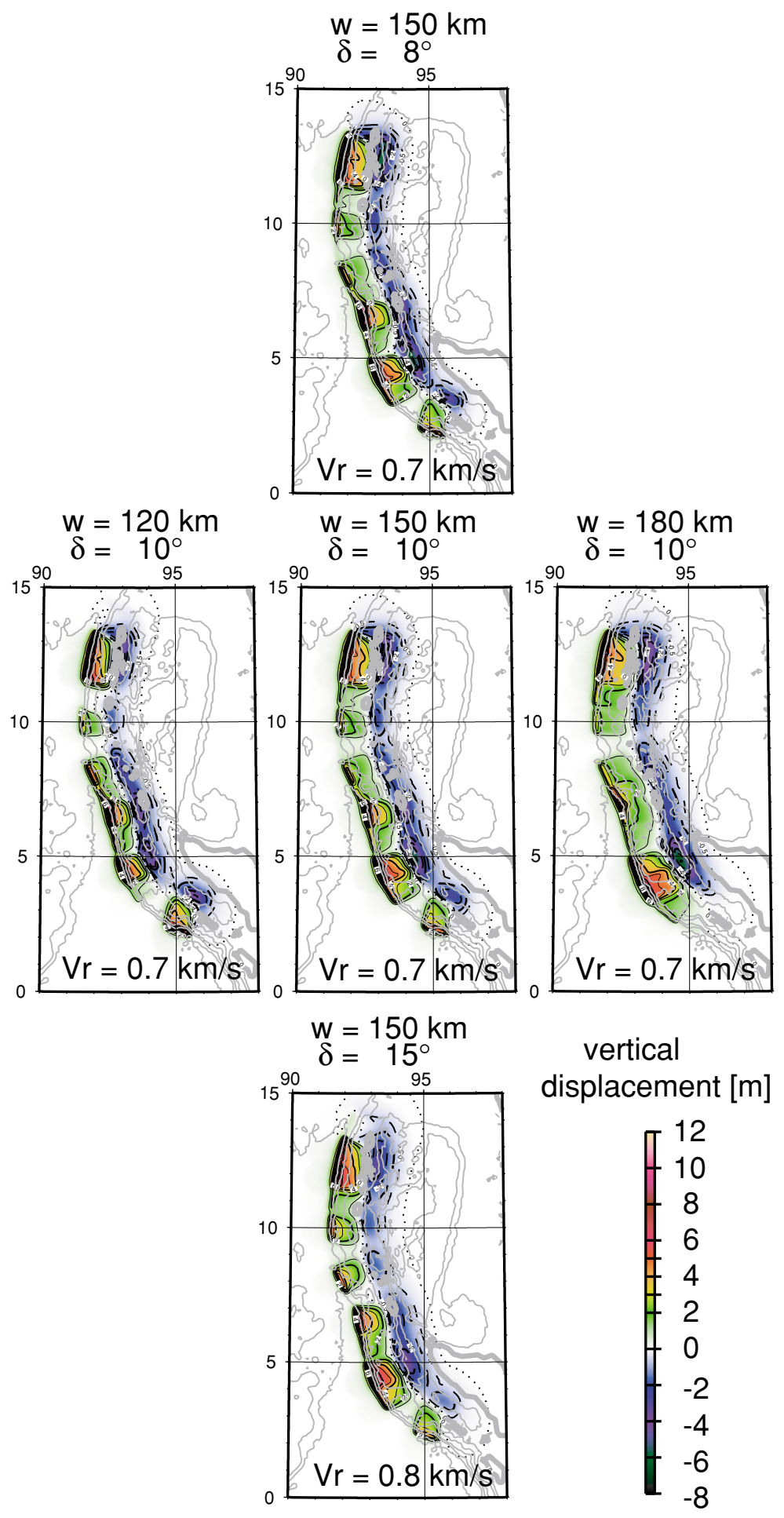

Fig. 4. Model seafloor deformation patterns calculated from best-fit source models with various widths $(w)$ and dip angles $(\delta)$ of subfaults. Average propagation velocity $(\mathrm{Vr})$ that produces minimum variance in prescribed width and dip angle pair is shown within each panel.

in Fig. 1(a). We set the grid size of the computation as 3 minute of arc $(\sim 5 \mathrm{~km})$, small enough to represent minimum wavelength $(\sim 200 \mathrm{~km})$ of the Indian Ocean tsunami observed with two satellites. The grid data are made from ETOPO2 (Smith and Sandwell, 1997). The computation is made at every $5 \mathrm{sec}$, satisfying the stability condition of finite difference computation. By using satellite orbital information (latitude, longitude, and time) and a priori propagation velocity $(V r)$, we then construct satellite pass-segment
Greens functions to use them in the linear inversion. We apply a linear inversion scheme with a non-negative constraint to solve this inversion problem. A rise time, $150 \mathrm{sec}$, of seafloor deformation is used because it produces minimum variance.

\section{Results}

Since the epicenter of offshore earthquake is, in general, poorly located, we first examine the rupture initiation point. 
We assume four rupture starting points: $\mathrm{O}_{1}, \mathrm{O}_{2}, \mathrm{O}_{3}$, and $\mathrm{O}_{4}$ as shown in Fig. 1(b). Point $\mathrm{O}_{1}$ is located on the southeast edge of subfault E1 and consistent with USGS/NEIC epicenter. Point $\mathrm{O}_{2}$ is $50 \mathrm{~km}$ from $\mathrm{O}_{1}$ along the trench, $\mathrm{O}_{3}$ is $50 \mathrm{~km}$ from $\mathrm{O}_{2}$, and $\mathrm{O}_{4}$ is set at the center of subfault $\mathrm{E} 2$.

Figure 3 shows normalized variances as a function of average propagation velocity $(V r)$ and suggests that the tsunami source propagated from $\mathrm{O}_{1}$ unilaterally to NNE, although difference in the normalized variance is small. A minimum normalized variance of 0.281 is obtained at propagation velocity of $V r=0.7 \mathrm{~km} / \mathrm{sec}$. Such a slow propagation feature is less affected by assumed dip angle and fault width: in the cases of different values in subfault dip angle and width, overall seafloor deformation pattern is not changed largely and the best-fit propagation velocity is always between $0.7 \mathrm{~km} / \mathrm{sec}$ and $0.8 \mathrm{~km} / \mathrm{sec}$ (Fig. 4). The best-fit solutions suggest that the tsunami source did not reach near northernmost subfault E14. Thus, the entire fault length measured parallel to the concaved trench axis is 1300 $\mathrm{km}$. The extremely slow propagation model reproduces a fairly good synthetic SSH distribution (Fig. 2(a)) whereas fast propagation models with velocity of a few $\mathrm{km} / \mathrm{sec}$ do not explain the observed trough with wide south-facing slope between $6^{\circ} \mathrm{N}$ and $19^{\circ} \mathrm{N}$ in Jason-1 data (Fig. 2(b)). Lay et al. (2005) explained the Jason-1 SSH data by introducing a combination of a fast rupture $(V r=2 \mathrm{~km} / \mathrm{s}$, rise time $=50 \mathrm{~s})$ in the southern $745 \mathrm{~km}$ segment and a slow rupture $(V r=0.75 \mathrm{~km} / \mathrm{s}$, rise time $=3500 \mathrm{~s})$ in the northern segment. Slow propagation estimated by the present study may correspond to the slow rupture component of Lay et al. (2005), although it is difficult to compare our result with theirs, because we do not vary propagation velocity and rise time during the tsunami source propagation.

It is also worth noting that instantaneous propagation models (i.e., $V r=\infty \mathrm{km} / \mathrm{sec}$ ) that are traditionally used in tsunami modeling yield minimum variances much larger than the $1300 \mathrm{~km}$-long tsunami source propagating model; minimum normalized variances for instantaneous propagation models on the southern $700 \mathrm{~km}, 900 \mathrm{~km}, 1200 \mathrm{~km}$, and $1300 \mathrm{~km}$ segments are $0.604,0.503,0.461$, and 0.421 , respectively. Previously estimated tsunami source of 600 to $800 \mathrm{~km}$-long seems to be underestimated due to the traditional assumption of instantaneous tsunami excitation over entire tsunami source area. The best solution for $V r=0.7$ $\mathrm{km} / \mathrm{sec}$ is listed in Table 1 .

\section{Discussions and Conclusion}

The northern extent and propagation velocity of the tsunami source can also be examined by tsunami travel times at northern tide gauge stations. Paradip and Vishakhapatnam are two northernmost stations (Fig. 1(a)). The observed travel times at both stations are 156 minutes (Department of Ocean Development, 2005). To estimate the source extent from the tsunami travel time, we have to correct for the rupture propagation with a finite velocity. Corrected travel times $T c=T-T p$ are simply estimated by subtracting $T p=L / V r$ from observed travel times $\mathrm{T}$, where $L$ is the along-trench distance between the epicenter and effective tsunami generation point which can be thought to be "nearest (in tsunami diffraction diagram)" to a tide gauge station. $L$ always equals to length $(L s)$ of the tsunami source and is the same for Paradip and Vishakhapatnam except for $L s \geq 1300 \mathrm{~km}$. For $L s \geq 1300 \mathrm{~km}, L$ equals to $L s$ for Paradip but not for Vishakhapatnam; graphical inspection of tsunami diffraction diagram shows that subfault E13 is slightly nearer to Vishakhapatnam than subfault E14. For Vishakhapatnam, therefore, we fix $L=1250 \mathrm{~km}$, which is the distance from the epicenter to the center of subfault E13.

Tsunami source should be outlined by back-projecting tsunami wavefronts (black curves in Fig. 5) if shallow bathymetry of ETOPO2, location of tide gauge on bathymetric grid, and tide gauge clocks are all accurate, and subfault geometry is appropriate. Since we cannot exclude these error factors, we introduce allowable range of \pm 10 min in corrected travel times. If outline of a tsunami source is included in both of the allowable ranges (blue curves for Paradip and red curves for Vishakhapatnam in Fig. 5), the tsunami source is considered acceptable.

Figure 5(a) suggests that slow propagating source models with velocities from $0.6 \mathrm{~km} / \mathrm{sec}$ to $1.0 \mathrm{~km} / \mathrm{sec}$ are acceptable for $L s \geq 1300 \mathrm{~km}$. Propagation velocities from $0.7 \mathrm{~km} / \mathrm{sec}$ to $0.9 \mathrm{~km} / \mathrm{sec}$ are acceptable if allowable range is set $\pm 5 \mathrm{~min}$ whereas those from $0.5 \mathrm{~km} / \mathrm{sec}$ to $1.5 \mathrm{~km} / \mathrm{sec}$ are acceptable if allowable range is set $\pm 15 \mathrm{~min}$.

Figure 5(b) suggests that no acceptable solution is obtained in velocity interval from $0.5 \mathrm{~km} / \mathrm{sec}$ to $3.0 \mathrm{~km} / \mathrm{sec}$ for $700 \mathrm{~km}$-long tsunami source models $(L s=700 \mathrm{~km})$ when allowable range is set $\pm 10 \mathrm{~min}$ No acceptable solution is obtained in the same velocity interval when allowable range is set $\pm 5 \mathrm{~min}$ or $\pm 15 \mathrm{~min}$. Long tsunami source with slow propagating velocity, therefore, seems to be a probable solution.

Average propagation velocity of the tsunami source was estimated from the inversion to be an extremely slow $V r=0.7 \mathrm{~km} / \mathrm{sec}$ or so. Total source duration is, therefore, roughly estimated to be $1300 \mathrm{~km} / 0.7 \mathrm{~km} / \mathrm{sec}=1900$ $\mathrm{sec}$ or 30 minutes, approximately four times longer than source duration estimates (480-500 sec) from short-period $P$-waves (Ishii et al., 2005; Ni et al., 2005; Kruger and Ohrnberger, 2005). When average propagation velocity is $0.6 \mathrm{~km} / \mathrm{sec}$ or $1.0 \mathrm{~km} / \mathrm{sec}$, total source duration becomes $1400 \mathrm{~km} / 0.6 \mathrm{~km} / \mathrm{sec}=2300 \mathrm{sec}(\sim 40 \mathrm{~min})$ or $1300 \mathrm{~km} / 1.0$ $\mathrm{km} / \mathrm{sec}=1300 \mathrm{sec}(\sim 20 \mathrm{~min})$.

The large amount of slip, which produces the large seafloor deformation, is identified on subfault E4 closest to west coast of the northern Sumatra when longer tsunami source models with slow propagation are concerned. The strong local tsunami source is probably responsible to the observed large tsunami height of approximately $35 \mathrm{~m}$ or 49 $\mathrm{m}$ at west coast of northern Sumatra (International Tsunami Survey Team, 2005; Tsunami Field Survey Team in Banda Aceh of Indonesia, 2005). Slip distribution estimated from seismic wave studies (Ji, 2005; Taymaz et al., 2005; Yagi, 2005; Yamanaka, 2005) also suggested large asperity in the almost same region.

Although the inversion suggests that large amount of slip was occurred on subfaults E12 and E13, a close examination of satellite pass-segment Green functions implies that subfault E13 may not be well constrained if $V r$ is 0.7 
(a)
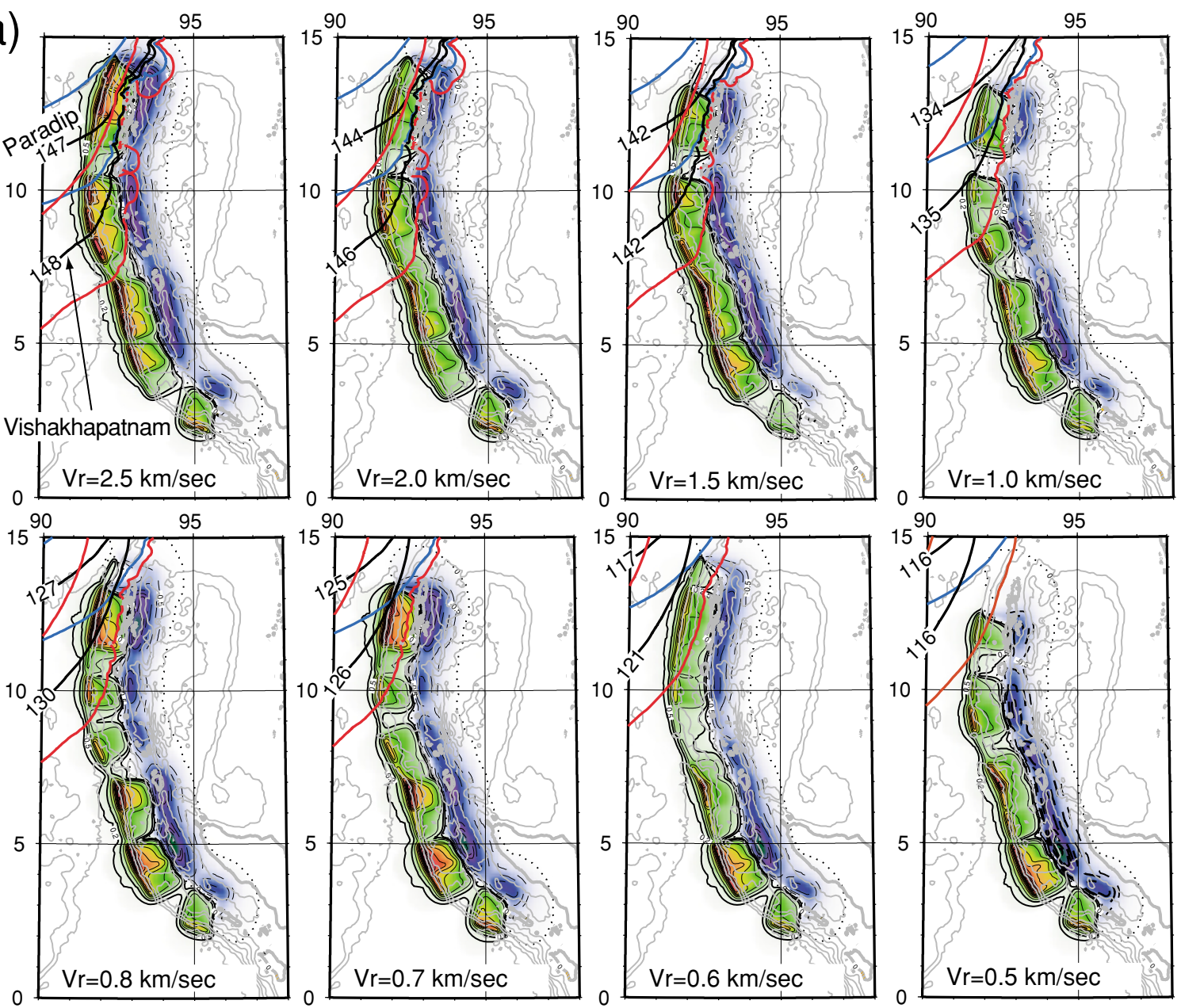

(b)

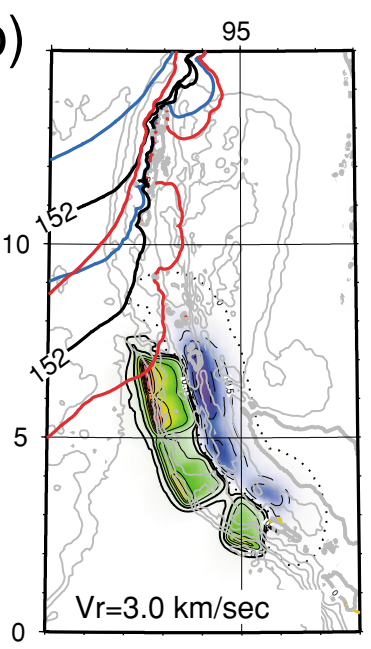

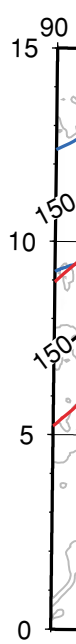
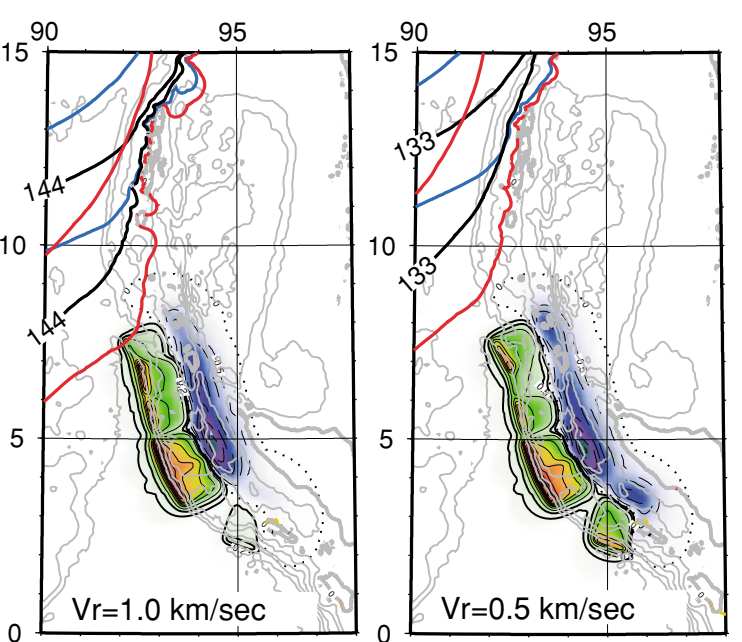

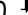

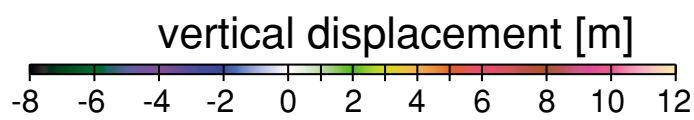

Fig. 5. Comparison of various tsunami source models (model seafloor deformation patterns calculated from best-fit source models inverted from SSH data) with corrected tsunami travel times at the northernmost tide gauge stations, Paradip and Vishakhapatnam. Black curves indicate imaginary back-projecting tsunami wavefront with the corrected travel times (see the text) calculated based on ETOPO2 bathymetry. Blue and red curves sandwiching the black curves represent the allowable range $( \pm 10 \mathrm{~min})$ of corrected travel times for Paradip and Vishakhapatnam, respectively. Average propagation velocity $V r$ is shown in the bottom of each panel. (a) Comparison between corrected travel times and long tsunami sources estimated when $1400 \mathrm{~km}$-long segment is allowed to generate tsunami. (b) Comparison between corrected travel times and short tsunami sources estimated when tsunami source is limited in southern $700 \mathrm{~km}$-long segment. 
$\mathrm{km} / \mathrm{sec}$ because the southward-traveling leading wave crest from E13 coincidentally falls in one of the Jason-1 data gaps between $5^{\circ} \mathrm{N}$ and $6^{\circ} \mathrm{N}$. Since third largest amount of slip on subfault E12 is well constrained from the observed SSH data, the tsunami source had to propagate at least $1200 \mathrm{~km}$ to the north from the epicenter along the trench. Tsunami source models that are confined in the $700 \mathrm{~km}$-long Sumatra and Nicobar segments cannot explain observed wide trough between $6^{\circ} \mathrm{N}$ and $19^{\circ} \mathrm{N}$ in Jason-1 data (Fig. 2(b)). Large amount of slip near Andaman Island, however, may not be explained smaller tsunami heights of $1-5 \mathrm{~m}$ in the Andaman Islands (Department of Ocean Development, 2005). Slow seafloor deformation (long rise time) in this region may be required.

Our inversion result suggests total seismic moment $M o=9.86 \times 10^{22} \mathrm{Nm}(\mathrm{Mw}=9.3)($ Table 1$)$. This estimate is 2.5 times larger than the previous estimate by USGS/NEIC and Harvard CMT but nearly the same as that of the longest period normal mode study (Stein and Okal, 2005). The average dislocation is approximately $14 \mathrm{~m}$ along the entire $1300 \mathrm{~km}$-long fault.

Acknowledgments. We appreciate Eric L. Geist for reading the earlier version of the manuscript and two anonymous reviewers for their comments the manuscript. This research was supported by an emergency scientific fund to the 2004 Sumatra earthquake and Special Coordination funds for promoting science and technology from the Ministry of Education, Culture, Sports, Science and Technology (MEXT), Japanese government, and the research program at the Institute for Research on Earth Evolution(IFREE), JAMSTEC. Figures were partially drawn using GMT software (Wessel, P. and W. H. F. Smith, EOS, Trans. AGU, 76, 329, 1995).

\section{References}

Araki, E., M. Shinohara, K. Obana, T. Yamada, Y. Kaneda, T. Kanazawa, and K. Suyehiro, Aftershock distribution of the 26 December 2004 Sumatra-Andaman earthquake from ocean bottom seismographic observation, Earth Planets Space, 58, this issue, 113-119, 2005.

Department of Ocean Development, http://dod.nic.in/tsunami.pdf, 2005.

Engdahl, E. R., R. Van der Hilst, and R. Bulan, Global teleseismic earthquake relocation with improved travel times and procedures for depth determination, Bull. Seismol. Soc. Am., 88, 722-743, 1998.
Gower, J., Jason-1 detects the 26 December 2004 tsunami, EOS, trans. $A G U, \mathbf{8 6}, 4,37-38,2005$.

International Tsunami Survey Team leaded by Dr. Y. Tsuji, http://www.eri. u-tokyo.ac.jp/namegaya/sumatera/surveylog/eindex.htm, 2005.

Ishii, M., P. M. Sharer, H. Houston, and J. E. Vidale, Extent, duration and speed of the 2004 Sumatra-Andaman earthquake imaged by the Hi-Net array, Nature, 435, 933-936, 2005.

Ji, C., http://neic.usgs.gov/neis/eq_depot/2004/eq_041226/neic_slav_ff.html, 2005.

JPL/NASA, http://sealevel.jpl.nasa.gov/mission/jason-1.html \& http:// sealevel.jpl.nasa.gov/mission/topex.html, 2005.

Kruger, F. and M. Ohrnberger, Tracking the rupture of the $\mathrm{Mw}=49.3$ Sumatra earthquake over $1,150 \mathrm{~km}$ at teleseismic distance, Nature, $\mathbf{4 3 5}$, 937-939, 2005.

Lay, T., H. Kanamori, C. J. Ammon, M. Nettles, S. N. Ward, R. C. Aster, S. L. Beck, S. L. Bilek, M. R. Brudzinski, R. Butler, H. R. DeShon, G. Ekstrom, K. Satake, and S. Sipkin, The great Sumatra-Andaman earthquake of 26 December 2004, Science, 308, 1127-1133, 2005.

$\mathrm{Ni}, \mathrm{S} ., \mathrm{H}$. Kanamori, and D. Helmberger, Energy radiation from the Sumatra earthquake, Nature, 434, 582, 2005.

Okada, Y., Surface deformation due to shear and tensile faults in a half space, Bull. Seismol. Soc. Am., 75, 1135-1154, 1985.

Satake, K., Linear and non-linear computations of the 1992 Nicaragua earthquake tsunami, Pure Appl. Geophys., 144, 455-470, 1995.

Simoes, M., J. P. Avouac, R. Cattin, and P. Henry, The Sumatra subduction zone: A case for a locked fault zone extending into the mantle, $J$. Geophys. Res., 109, B10402, doi:10.1029/2003JB002958, 2004.

Smith, W. H. F. and D. T. Sandwell, Global sea floor topography from satellite altimetry and ship depth soundings, Science, 277, 1956-1962, 1997.

Stein, S. and E. Okal, Speed and size of the Sumatra earthquake, Nature, 434, 581-582, 2005.

Taymaz, T., O. Tan and S. Yolsal, http://www.geop.itu.edu.tr/ taymaz/ sumatra/, 2005.

Titov, V., http://www.noaanews.noaa.gov/stories2005/s2365.htm, 2005.

Tsunami Field Survey Team in Banda Aceh of Indonesia, http://www.drs. dpri.kyoto-u.ac.jp/sumatra/indonesia-ynu/indonesia_survey_ynu_e.html, 2005.

Yagi,Y.,http://iisee.kenken.go.jp/staff/yagi/eq/Sumatra2004/Sumatra2004. html, 2005.

Yamanaka, Y., http://www.eri.u-tokyo.ac.jp/sanchu/Seismo_Note/2004/ EIC161ea.html, 2005.

K. Hirata (e-mail: hiratak@jamstec.go.jp), K. Satake (e-mail: kenji.satake@aist.go.jp), Y. Tanioka (e-mail: tanioka@eos.hokudai.ac.jp), T. Kuragano (e-mail: kuragano@met.kishou.go.jp), Y. Hasegawa (email: yhasegaw@mri-jma.go.jp), Y. Hayashi (e-mail: yhayashi@mrijma.go.jp), and N. Hamada (e-mail: nhamada@met.kishou.go.jp) 